\title{
Recurrent pterygium in Bintulu, Sarawak (Malaysian Borneo): determining its risk factors
}

Loshni Murugia ${ }^{1}$, Chong Ka Lung ${ }^{1}$, Lim Lik Thai ${ }^{2,3}$, Rohanah Alias ${ }^{4}$

${ }^{1}$ Ophthalmology Department, Hospital Bintulu, Sarawak, Malaysia; '2Universiti Malaysia Sarawak (UNIMAS), Sarawak, Malaysia; ${ }^{3}$ Sarawak General Hospital, Sarawak, Malaysia; ${ }^{4}$ Ophthalmology Department, Hospital Kuala Lumpur, Kuala Lumpur, Malaysia

\section{Abstract}

Introduction: Pterygium may give rise to astigmatism in addition to causing blindness in advanced stages, reflecting the importance of timely surgical intervention. Despite various operative approaches, the recurrence rate continues to range from $2 \%$ to $89 \%$. Therefore, it is essential to investigate the risk factors influencing recurrence to improve therapeutic strategies.

Purpose: To determine the risk factors of pterygium recurrence among the multiethnic cohort of patients of Bintulu, Sarawak (Malaysian Borneo).

Study design: Retrospective cohort.

Materials and methods: This study was conducted in Bintulu Hospital, Sarawak (Malaysian Borneo) and involved patients who underwent pterygium excision with conjunctival autografting between April 1, 2016 and May 31, 2019. Patients completed at least a year of follow-up for recurrence detection. Collected data included presence of recurrence, sociodemographics, outdoor activities, habits, first-degree family history, pterygium type and location, as well as laterality. Chi-squared test, Fisher's exact test, and logistic regression analysis were used.

Results: A total of 161 eyes that underwent pterygium excision in 137 patients were identified. Percentage of recurrence was found to be $42 \%$. The mean age during excision was $59.3 \pm 11.5$ years; age group showed no significance in pterygium recurrence $(p=0.447)$. Male gender showed statistical significance $(p=0.045$, OR $1.90, \mathrm{Cl} 1.01,3.58)$ in chi-squared test but not in logistic regression. Ethnicity,

Correspondence: Dr.Loshni Murugia, MD, Ophthalmology Department, Hospital Bintulu, Jalan Bukit Nyabau, 97000, Bintulu, Sarawak, Malaysia.

E-mail:loshni66@gmail.com 
marital status, income, and education level showed no association with recurrence $(p>0.05)$. Anatomic factors like location $(p=0.353)$ and laterality $(p=0.955)$ also showed no association. Smoking $(p=0.867)$ and alcohol intake $(p=0.397)$ were insignificant, similar to first-degree family history $(p=0.137)$. Activities involving sun exposure $(p<0.001$, OR $18.34,95 \% \mathrm{Cl} 5.59,60.17)$ and recurrent pterygium type ( $p=$ 0.001 , OR $7.40,95 \% \mathrm{Cl} 1.81,30.21$ ) supported a positive association with recurrence. Medication adherence ( $p<0.001$, OR 3.61, 95\% Cl 1.07, 12.21) and the use of sun protection ( $p<0.001$, OR $7.90,95 \% \mathrm{Cl} 3.25,19.19)$ showed a statistically significant decrease in recurrence.

Conclusion: Activities involving sun exposure, use of sun protection, medication adherence, and recurrent pterygium type have shown to be statistically significant in influencing recurrence after excision and conjunctival autograft.

Keywords: conjunctival grafting, pterygium, pterygium excision, recurrence, risk factors

\section{Pterigium berulang di Bintulu, Sarawak (Borneo Malaysia): penentuan faktor risiko}

\section{Abstrak}

Pendahuluan: Pterigium dapat menimbulkan astigmatisme selain menyebabkan kebutaan pada tahap lanjut, yang menggambarkan pentingnya campur tangan pembedahan tepat pada masanya. Walaupun terdapat pelbagai pendekatan pembedahan, kadar pengulangan terus berkitar antara 2\% hingga $89 \%$. Oleh itu, adalah mustahak untuk menyelidik faktor risiko yang mempengaruhi kes berulang dan memperbaiki strategi terapi.

Tujuan: Untuk menentukan faktor risiko berulang pterigium di antara kohort pesakit pelbagai etnik Bintulu, Sarawak (Borneo Malaysia).

Reka bentuk kajian: Kumpulan retrospektif.

Bahan dan kaedah: Kajian ini dilakukan di Hospital Bintulu, Sarawak (Borneo Malaysia) dan melibatkan pesakit yang menjalani eksisi pterigium dengan cantuman autograf konjunktiva antara 1 April 2016 dan 31 Mei 2019. Pesakit menyelesaikan sekurang-kurangnya satu tahun susulan lanjut untuk pengesanan kes berulang. Data yang dikumpulkan termasuk kehadiran berulang, sosiodemografi, aktiviti luar, kebiasaan, sejarah keluarga darjah pertama, lokasi dan jenis serta kelateralan pterigium. Uji Chi-kuadrat, uji tepat Fisher, dan analisis regresi logistik digunakan. Dapatan: Sebanyak 161 mata yang menjalani eksisi pterigium pada 137 pesakit dikenal pasti. Peratusan berulang didapati 42\%. Umur min semasa eksisi adalah 59.3 
\pm 11.5 tahun; kumpulan umur tidak menunjukkan kepentingan dalam kambuhan pterigium ( $p=0.447$ ). Jantina lelaki menunjukkan kepentingan statistik ( $\mathrm{p}=0.045$, OR 1.90, CI 1.01, 3.58) dalam ujian chi-square tetapi tidak dalam regresi logistik. Etnik, status perkahwinan, pendapatan, dan tahap pendidikan tidak menunjukkan hubungan dengan kambuhan $(p>0.05)$. Faktor anatomi seperti lokasi $(p=0.353)$ dan lateral $(p=0.955)$ juga tidak menunjukkan perkaitan. Merokok $(\mathrm{p}=0.867)$ dan pengambilan alkohol $(p=0.397)$ tidak signifikan, serupa dengan sejarah keluarga darjah pertama $(p=0.137)$. Aktiviti yang melibatkan pendedahan cahaya matahari $(p<0.001$, OR $18.34,95 \%$ CI 5.59, 60.17) dan jenis pterigium berulang $(p=0.001$, atau $7.40,95 \%$ CI 1.81, 30.21) menyokong hubungan positif dengan berulang. Kepatuhan ubat $(p<0.001$, OR 3.61, 95\% CI 1.07, 12.21) dan penggunaan pelindung cahaya matahari ( $<<0.001$, OR $7.90,95 \%$ CI $3.25,19.19)$ menunjukkan penurunan berulang secara statistik.

Kesimpulan: Kegiatan yang melibatkan pendedahan cahaya matahari, penggunaan pelindung sinar matahari, kepatuhan terhadap ubat-ubatan, dan jenis pterigium berulang telah terbukti signifikan secara statistik dalam mempengaruhi kes berulang selepas eksisi dan autograf konjunktiva.

Kata kunci: berulang, cantuman graf konjunktiva, eksisi pterigium, faktor risiko, pterigium

\section{Introduction}

Pterygium is an ocular surface disease in which there is a benign, uncontrolled growth involving epithelial hyperplasia, hyperproliferation of vessels, and elastotic degeneration of the bulbar conjunctiva onto the cornea. ${ }^{1,2}$ Besides causing debilitating blindness in advanced stages, pterygium may give rise to refractive astigmatism and is cosmetically unappealing, which conclusively reflects the importance of surgical intervention. ${ }^{3}$ Worldwide, studies have shown that the prevalence of pterygium ranges between $0.07 \%$ and $53 \% .{ }^{4}$ Pterygium is noted to be more prevalent within the "pterygium belt" located between $30^{\circ}$ north and south of the equator. ${ }^{5}$ Malaysia is located in the presumed "pterygium belt" along with its neighbours India, Singapore, Indonesia, Japan, and Nepal, for which pterygium prevalence is $11.7 \%, 10.1 \%, 10 \%, 4.4 \%$, and $10.08 \%$, respectively. ${ }^{6-11} \mathrm{~A}$ study done in West Malaysia reported a $7.4 \%$ prevalence of pterygium, while in East Malaysia studies are yet to be conducted. ${ }^{12}$

Surgery has been widely used in the treatment of pterygium, which mainly includes leaving the sclera bare after excision and excision with either conjunctival autograft, conjunctival minigraft, or amniotic membrane grafting. ${ }^{13}$ Other treatment approaches include adjunctive therapies such as thiotepa, mitomycin, or beta irradiation postoperatively or intraoperative mitomycin besides cautery 
and excimer laser treatment. ${ }^{14}$ Despite surgery being the single most practical way to treat pterygium, recurrence rates continue to range from $2 \%$ to $89 \%$ with various operative approaches. ${ }^{15,16}$ Therefore, it is essential to investigate the risk factors involved in pterygium recurrence in order to improve therapeutic strategies, especially in light of the fact that it has tendency to proliferate more aggressively during recurrence. ${ }^{1}$ In addition, various authors have addressed the need for research on the effect of ethnicity and other risk factors as prognosticators of postoperative pterygium recurrence in a controlled fashion. ${ }^{14,17}$ Ethnicity in particular has consistently been overlooked as a potential predictor due to the assumed homogeneity of the research subjects. ${ }^{17,18}$

To the best of our knowledge, a study regarding the risk factors of pterygium recurrence has yet to be done in an equatorial population. In our case, Bintulu is located $3^{\circ}$ north of the equator and its multiethnic population, living in the same geographical area, provides an exceptional opportunity to study it from a single health facility. This study was intended to investigate the postoperative recurrence of pterygium in association with demographic, environmental, habitual, anatomic, and familial predisposition factors.

\section{Materials and methods}

This study was conducted in compliance with the ethical principles outlined in the Declaration of Helsinki as well as the Malaysian Good Clinical Practice Guideline and obtained ethical clearance from the country's Medical Research and Ethics Committee. This retrospective cohort study involved patients who underwent pterygium excision with conjunctival autografting and completed at least 1 year of follow-up in Bintulu Hospital. Recruitment of subjects was done from patients who underwent the procedure between April 1, 2016 and May 31, 2019. These patients were identified and approached during their regular follow-up at the clinic.

Written informed consent was obtained and patients were interviewed to obtain demographic data (age during excision, gender, ethnicity, education level, income, marital status), information on lifestyle as well as habits (activities involving sun exposure, smoking, use of sun protection, postoperative medication adherence, alcohol consumption), and familial predisposition. Household income was calculated from the total income of each household member. Households were grouped into quintiles according to income. ${ }^{19}$ Sun exposure was considered significant when outdoor activities involved sun exposure for more than 5 hours per day. ${ }^{4,20}$ Non-smokers were categorised as those who had never smoked or smoked less than five packs in their lifetime. ${ }^{4,20}$ Sun protection included the use of hats, sunglasses, umbrellas, or shades during outdoor activities and was categorised using Likert-scale answers. ${ }^{21,22}$ Medication adherence was defined as taking $80 \%$ or more of the prescribed medication doses. ${ }^{23}$ Prescribed medications referred to 
Table 1. Univariate and multivariate analysis of variables in patients with and without recurrence

\begin{tabular}{|c|c|c|c|c|}
\hline \multirow{2}{*}{ Characteristics } & \multicolumn{2}{|c|}{ Recurrence } & \multirow{2}{*}{ AOR $(95 \% \mathrm{CI})$} & \multirow{2}{*}{ P-value } \\
\hline & Yes (\%) & No & & \\
\hline \multicolumn{5}{|l|}{ Age during excision } \\
\hline$<40$ & $2(40 \%)$ & 3 & & $0.447^{b}$ \\
\hline $40-49$ & $11(34.4 \%)$ & 21 & & \\
\hline $50-59$ & $23(52.3 \%)$ & 21 & & \\
\hline$>60$ & $33(41.3 \%)$ & 47 & & \\
\hline \multicolumn{5}{|l|}{ Gender } \\
\hline Male & $41(50.6 \%)$ & 40 & $1.90(1.01,3.58)(\mathrm{COR})$ & $0.045^{\mathrm{a}}$ \\
\hline Female & 28 (35\%) & 52 & & \\
\hline \multicolumn{5}{|l|}{ Ethnicity } \\
\hline Malay & $7(43.8 \%)$ & 9 & & $0.607^{\mathrm{a}}$ \\
\hline Chinese & $10(38.5 \%)$ & 16 & & \\
\hline Iban & $34(39.5 \%)$ & 52 & & \\
\hline Melanau & $13(52.0 \%)$ & 12 & & \\
\hline Others & $5(62.5 \%)$ & 3 & & \\
\hline \multicolumn{5}{|l|}{ Marital status } \\
\hline Single & $3(37.5 \%)$ & 5 & & $0.485^{\mathrm{a}}$ \\
\hline Married & $52(41.9 \%)$ & 72 & & \\
\hline $\begin{array}{l}\text { Widower/Widow/ } \\
\text { Divorcee }\end{array}$ & $14(48.3 \%)$ & 15 & & \\
\hline \multicolumn{5}{|l|}{ Education level } \\
\hline No formal education & 21 (41.2\%) & 30 & & $0.953^{\mathrm{a}}$ \\
\hline Primary education & $20(44.4 \%)$ & 25 & & \\
\hline Secondary education & $23(41.8 \%)$ & 32 & & \\
\hline Tertiary education & $5(50 \%)$ & 5 & & \\
\hline \multicolumn{5}{|l|}{ Income } \\
\hline $1^{\text {st }}$ quintile & $16(38.1 \%)$ & 26 & & $0.642^{\mathrm{a}}$ \\
\hline $2^{\text {nd }}$ quintile & $15(38.5 \%)$ & 24 & & \\
\hline $3^{\text {rd }}$ quintile & $23(50 \%)$ & 23 & & \\
\hline $4^{\text {th }}$ quintile & $15(44.1 \%)$ & 19 & & \\
\hline
\end{tabular}




\begin{tabular}{|c|c|c|c|c|}
\hline \multirow{2}{*}{ Characteristics } & \multicolumn{2}{|c|}{ Recurrence } & \multirow{2}{*}{ AOR $(95 \% \mathrm{CI})$} & \multirow{2}{*}{ P-value } \\
\hline & Yes (\%) & No & & \\
\hline \multicolumn{5}{|l|}{ Location } \\
\hline Nasal & $47(40.2 \%)$ & 70 & & $0.353^{b}$ \\
\hline Temporal & $3(75 \%)$ & 1 & & \\
\hline Both & $19(47.5 \%)$ & 21 & & \\
\hline \multicolumn{5}{|l|}{ Laterality } \\
\hline Unilateral & $14(42.4 \%)$ & 19 & & $0.955^{\mathrm{a}}$ \\
\hline Bilateral & $55(43 \%)$ & 73 & & \\
\hline \multicolumn{5}{|l|}{ Smoking } \\
\hline Smoker & $15(44.1 \%)$ & 19 & & $0.867^{a}$ \\
\hline Non-smoker & $54(42.5 \%)$ & 73 & & \\
\hline \multicolumn{5}{|l|}{ Alcohol Intake } \\
\hline Abstinent & $66(43.7 \%)$ & 85 & & $0.397^{\mathrm{b}}$ \\
\hline Light drinking & $1(25 \%)$ & 3 & & \\
\hline Moderate drinking & $0(0 \%)$ & 3 & & \\
\hline Unsafe drinking & $2(66.7 \%)$ & 1 & & \\
\hline \multicolumn{5}{|c|}{ First-degree family history of pterygium } \\
\hline Yes & $28(50.9 \%)$ & 27 & & $0.137^{\mathrm{a}}$ \\
\hline No & $41(38.7 \%)$ & 65 & & \\
\hline \multicolumn{5}{|c|}{ Activities involving sun exposure } \\
\hline Yes & $30(85.7 \%)$ & 5 & $18.34(5.59,60.17)$ & $<0.001$ \\
\hline No & $39(31 \%)$ & 87 & & \\
\hline \multicolumn{5}{|c|}{ Medication adherence } \\
\hline Yes & $46(34.6 \%)$ & 87 & & \\
\hline No & $23(82.1 \%)$ & 5 & $3.61(1.07,12.21)$ & $<0.001$ \\
\hline \multicolumn{5}{|c|}{ Use of sun protection } \\
\hline $\begin{array}{l}\text { Never/Rarely/ } \\
\text { Sometimes }\end{array}$ & $39(68.4 \%)$ & 18 & $7.90(3.25,19.19)$ & $<0.001$ \\
\hline Often/Always & $30(28.8 \%)$ & 74 & & \\
\hline
\end{tabular}




\begin{tabular}{|l|l|l|l|l|}
\hline \multirow{2}{*}{ Characteristics } & \multicolumn{2}{l|}{ Recurrence } & \multirow{2}{*}{ AOR $(95 \% \mathrm{Cl})$} & \multirow{2}{*}{ P-value } \\
\cline { 2 - 6 } & Yes (\%) & No & & \\
\hline Pterygium type & $54(38 \%)$ & 88 & & 0.001 \\
\hline Primary & $15(78.9 \%)$ & 4 & $7.40(1.81,30.21)$ & \\
\hline Recurrent & $69(42 \%)$ & 92 & & \\
\hline Total &
\end{tabular}

apearson chi-square test

${ }^{\mathrm{b}}$ Fisher's test

AOR: adjusted odds ratio; COR: crude odds ratio

lubricant and steroid eye drops given postoperatively for 1 month. Patients were deemed "abstinent" if they consumed less than 1 unit of alcohol a week. "Light" drinking was defined as between 1 and $<7$ units a week and "moderate" drinking as 7 to $<14$ units a week. "Unsafe" drinking was defined as $>14$ units a week. ${ }^{24,25}$

Information regarding date of operation, duration of follow-up, age during surgery, laterality and location of pterygium, presence of recurrence, type of pterygium, and date of recurrence detection was obtained from the hospital information system. Recurrence of pterygium was defined as any fibrovascular growth extending across the limbus onto the cornea at the site of previous surgical excision. ${ }^{26}$ Patients who did not consent for this research and those with incomplete data were excluded.

All the information obtained was analysed for associations with pterygium recurrence using SPSS version 26 . The analytical statistics used were chi-square test and Fisher's exact test. Subsequently, variables that showed significant association in these tests were further analysed via multivariate logistic regression. Variables with $95 \%$ confidence interval $(\mathrm{Cl})$ and $p$-value $<0.05$ were considered statistically significant factors for pterygium recurrence.

\section{Results}

A total of 161 eyes from 137 patients who underwent pterygium excision from April 2016 to May 2019 were included in this study. Male-to-female ratio was noted to be almost 1:1(81 to 80 ). The mean age during excision was $59.3 \pm 11.5$ years. Percentage of recurrence was noted to be $42 \%$.

Table 1 summarises the risk factors investigated and the presence of recurrence. Most pterygium excisions (49.7\%) were performed in patients above 60 years of age. This demographic factor showed no significant difference when incorporated into Fisher'stest $(p=0.447)$. Malegenderwasstatisticallysignificant $(p=0.045)$, with a crude odds ratio (OR) of 1.90 and $\mathrm{Cl}$ of 1.01 to 3.58 when analysed using chi-squared test; 
however, once integrated in binary logistics, the value became non-significant. Other sociodemographic data, which included ethnicity, marital status, and education level, showed a $p>0.05$. Income, which was divided equally in quintiles, also appeared to be non-significant $(p=0.642)$. Location and laterality as anatomic factors also showed no significant difference, with $p$-values of 0.353 and 0.955 , respectively. The initial data was analysed with Fisher's test, while the latter with chi-squared test. Being known risk factors for many diseases, smoking $(p=0.867)$ and alcohol intake $(p=0.397)$ showed no association with recurrence in this study. Positive family history in first-degree relatives was analysed with chi-squared test and resulted in non-association with recurrence $(p=0.137)$.

Moving forward, all factors which showed significant difference when analysed with univariate analysis were assimilated into logistic regression to control confounding factors. Data on activities involving sun exposure yielded $p<$ 0.001 with OR $18.34(95 \% \mathrm{Cl} 5.59,60.17)$, supporting a positive association with recurrence. Medication adherence $(p<0.001$, OR 3.61, 95\% Cl 1.07, 12.21) and use of sun protection ( $p<0.001$, OR $7.90,95 \% \mathrm{Cl} 3.25,19.19)$ showed statistically significant decrease in recurrence. Recurrent pterygium type were 7.40 times more likely to cause recurrence compared to primary pterygium type $(p=0.001,95 \% \mathrm{Cl}$ 1.81, 30.21).

\section{Discussion}

The aim of this study was to determine the risk factors that contribute to pterygium recurrence after excision and conjunctival grafting in a multiethnic cohort of patients in Bintulu, Sarawak (Malaysian Borneo). Given its considerably high recurrence rate, it is essential for us to identify its risk factors in order to establish different therapeutic strategies as well as modify surveillance follow-up frequency and duration for those who are deemed to have higher tendency for recurrence. Intensive counselling on lifestyle and aggressive treatment approach may be administered in anticipation of recurrence. We performed our study retrospectively to analyse anatomy, sociodemographics, environment, lifestyle, and pterygium type as potential factors for recurrence.

Pterygium recurrence often develops in a short span of time after excision; therefore, sun exposure was assumed to be a rather negligible risk factor. ${ }^{1}$ This assumption was refuted in our study, which proved that sunlight exposure is a significant risk factor, further supporting similar studies conducted in Croatia, Spain, and Korea. ${ }^{27-29}$ In addition, lack of sun protection also appeared to be significantly associated with recurrence in this study. In fact, the burden may be higher in regions located in the "pterygium belt", in this case, our study site, Bintulu. Multiple studies have addressed the effect of UVB on limbal cells leading to production 
of interleukin (IL)-6, IL-8, and growth factors which is linked to inflammation, blood vessel formation, cellular proliferation, and antiapoptosis. ${ }^{30-32}$ Although the pathogenesis of recurrence due to sunlight has never been well documented, the previously mentioned molecular pathogenesis may possibly apply to any type of pterygium.

Recurrent pterygium itself was more likely associated with further recurrence as compared to primary pterygium in this study. A possible explanation for this could be the degree of expression of cyclooxygenase-2 (COX-2), which is said to be increased in stromal fibroblasts of recurrent pterygium in contrast to primary pterygium and is believed to be part of the pathogenesis of pterygium itself through its antiapoptotic nature..$^{33-35}$

The use of corticosteroids and artificial tears has been important in reducing the postoperative complications of pterygium, including recurrence. ${ }^{39-40}$ In our study site, both corticosteroids and artificial tears were given postoperatively; our results showed poor medical adherence be a significant risk factor in recurrence. Without proper consistent usage of these medications, the protective factor is no longer in place. This theory is supported by a recent study in Spain, which showed that tapering doses of corticosteroids within 5 weeks as compared to 4 months improved medication compliance and therefore resulted in less complications such as recurrence. ${ }^{40}$

Male gender showed significance in univariate analysis, but lost significance once incorporated into binary regression. This may be due to the disproportionately greater number of males exposed to the sun, possibly because of the nature of their occupation in Bintulu. Male gender as a predictive factor, however, seemed inconclusive as there have been mixed results in multiple studies. ${ }^{1,17,28,38,39}$

Younger age has been documented to be more prone towards recurrence in a few studies. ${ }^{1,38,40}$ Surprisingly, our study contradicts this, possibly due to an uneven distribution number of patients whereby most of the patients in our study were more than 60 years old.

This study has several limitations. The first is the lack of standardized surgical technique for pterygium excision due to the surgeries being performed by multiple surgeons using different surgical techniques, which may have influenced postoperative outcomes. The second is the patients who were lost to follow-up, who may have experienced recurrences but could not be included in our study. Finally, due to its retrospective nature, we were unable to obtain information on pterygium morphology prior to excision, which has been reported to influence recurrence in several studies.

In conclusion, activities involving sun exposure, the use of sun protection, medication adherence, and recurrent pterygium type have shown to be statistically significant in influencing recurrence after excision and conjunctival autograft in our multiethnic cohort of patients in Bintulu, Sarawak (Malaysian Borneo). 


\section{Acknowledgements}

We wish to express our gratitude to Madam Nurakmal Baharum, Clinical Research Centre (CRC, Kuala Lumpur, Malaysia), for her valuable assistance in the statistical analysis of this study. The authors have no conflict of interest or financial disclosures to declare.

\section{References}

1. Ha SW, Park JH, Shin IH, Kim HK. Clinical analysis of risk factors contributing to recurrence of pterygium after excision and graft surgery. Int J Ophthalmol. 2015;8(3):522-527.

2. Feng QY, Hu ZX, Song XL, Pan HW. Aberrant expression of genes and proteins in pterygium and their implications in the pathogenesis. Int J Ophthalmol. 2017;10(6):973-981.

3. Lü P, Chen XM. Prevalence and risk factors of pterygium. Int J Ophthalmol. 2008;8(5):871-874.

4. Alemayehu TK, Addis Y, Bizuneh ZY, Tegegne MM, Alemayehu AM. Prevalence and associated factors of pterygium among adults living in KollaDiba Town, Northwest Ethiopia. Clin Ophthalmol. 2020;14:245-255.

5. Detels R, Dhir SP. Pterygium: A Geographical Study. Arch Ophthalmol. 1967;78(4):485-491.

6. Marmamula S, Khanna RC, Rao GN. Population-based assessment of prevalence and risk factors for pterygium in the South Indian state of Andhra Pradesh: The Andhra Pradesh eye disease study. InvestigOphthalmol Vis Sci. 2013;54(8):5359-5366.

7. Ang M, Li X, Wong W, Zheng Y, Chua D, et al. Prevalence of and racial differences in pterygium: A multiethnic population study in Asians. Ophthalmology. 2012;119(8):1509-1515.

8. Gazzard G, Saw SM, Farook M, et al. Pterygium in Indonesia: Prevalence, severity and risk factors. $\mathrm{Br}$ J Ophthalmol. 2002;86(12):1341-1346.

9. Tano T, Ono K, Hiratsuka $\mathrm{Y}$, Otani K, et al. Prevalence of pterygium in a population in Northern Japan: The Locomotive Syndrome and Health Outcome in Aizu Cohort Study. Acta Ophthalmol. 2013;91(3):232-237.

10. Hashemi H, Khabazkhoob M, Yekta A, Jafarzadehpour E, Ostadimoghaddam H, Kangari H. The prevalence and determinants of pterygium in rural areas. J Curr Ophthalmol. 2017;29(3):194-198.

11. Maharjan I, Shreshth E, Gurung B, Karmacharya S. Prevalence of and associated risk factors for pterygium in the high-altitude communities of Upper Mustang, Nepal. Nepal J Ophthalmol. 2014;6(1):65-70.

12. Taylor SL, Coates ML, Vallejos Q, et al. Pterygium among Latino migrant farmworkers in North Carolina. Arch Environ Occup Health. 2006;61(1):27-32.

13. Ramalingam M, Joshi N, Nair J, Ali NAM. Outcome of surgical management of pterygium in Brunei Darussalam. Brunei Int Med J. 2011;7(1):8-14.

14. Hirst LW. The treatment of pterygium. SurvOphthalmol. 2003;48(2):145-180

15. He SY, Sun H, Huang Y, et al. Identification and Interaction Analysis of Significant Genes and MicroRNAs in Pterygium. BioMed Res Int. 2019;19:1-12. 
16. Fernandes M, Sangwan VS, Bansal AK, et al Outcome of pterygium surgery: analysis over 14 years. Eye (Lond). 2005;19(11):1182-1190.

17. Kandavel R, Kang JJ, Memarzadeh F, Chuck RS. Comparison of pterygium recurrence rates in hispanic and white patients after primary excision and conjunctival autograft. Cornea. 2010;29(2):141-145.

18. Campagna G, Adams M, Wang L, Khandelwal S, Al-Mohtaseb Z. Comparison of pterygium recurrence rates among different races and ethnicities after primary pterygium excision by surgeons in training. Cornea. 2018;37(2):199-204.

19. Institute for Public Health (IPH) 2015. National Health and Morbidity Survey 2015 (NHMS 2015). Vol. II: Non-Communicable Diseases, Risk Factors \& Other Health Problems; 2015.

20. Pyo EY, Mun GH, Yoon KC. The prevalence and risk factors for pterygium in South Korea: the Korea National Health and Nutrition Examination Survey (KNHANES) 2009-2010. Epidemiol Health. 2016;38:e2016015.

21. Peters CE, Koehoorn MW, Demers PA, Nicol AM, Kalia S. Outdoor Workers' Use of Sun Protection at Work and Leisure. Saf Health Work. 2016;7(3):208-12.

22. Brokalaki H, Patelarou E, Vardavas C, Elefsiniotis IS, Giakoumidakis KA, Brokalaki E. Current patterns of the sun protection measures adopted by nurses and the risk factors influencing their compliance. Open J Nurs. 2011;1(3):43-50.

23. Morrison A, Stauffer ME, Kaufman AS. Defining medication adherence in individual patients. Patient Prefer Adherence. 2015;9:893-897.

24. Topiwala A, Allan CL, Valanova V, et al. Moderate alcohol consumption as risk factor for adverse brain outcomes and cognitive decline: longitudinal cohort study. BMJ. 2017;357:j2353.

25. Department of Health. UK Chief Medical Officers' Low Risk Drinking Guidelines. Dep Heal Engl [Internet]. 2016;(August):1-11. Available from: https://www.gov.uk/.

26. Han SB, Jeon HS, Kim M, et al. Risk factors for recurrence after pterygium surgery: An image analysis study. Cornea. 2016;35(8):1097-103.

27. Sekelj S, Dekaris I, Kondža-Krstonijević E, Gabrić N, Predović J, Mitrović S. Ultraviolet light and pterygium. Coll Antropol. 2007;31(SUPPL. 1):45-47.

28. Torres-Gimeno A, Martínez-Costa L, Ayala G. Preoperative factors influencing success in pterygium surgery. BMC Ophthalmol. 2012;12(1):1-7.

29. Chun YH, Paik J-S, Oh JH, Kim H-S, Na K-S. Association between pterygium, sun exposure, and serum 25-hydroxyvitamin in a nationally representative sample of Korean adults. Lipids Health Dis. 2018;17(1):1-8.

30. Crăiţoiu S, Ciprian L, Rodica M, Mihai A, Anca El. Etiopathogenic aspects in development and evolution of pterigyum. Oftalmologia. 2008;52(2):29-34.

31. Di Girolamo N, Kumar RK, Coroneo MT, Wakefield D. UVB-mediated induction of interleukin-6 and -8 in pterygia and cultured human pterygium epithelial cells. InvestigOphthalmol Vis Sci. 2002;43(11):3430-3437.

32. Ginger-Eke HA, Ogbonnaya CE, Ezisi CN. Pterygium: Recent trends and perspectives - A review of pathogenesis and current management options. Niger J Ophthalmol. 2018;26(2):89-98.

33. Karahan N, Baspinar S, Ciris M, Baydar C, Kapucuoglu N. Cyclooxygenase-2 expression in primary and recurrent pterygium. Indian J Ophthalmol. 2008;56(4):279-283. 
34. Chiang CC, Cheng YW, Lin CL, Lee H, Tsai FJ, Tseng SH, et al. Cyclooxygenase 2 expression in pterygium. Mol Vis. 2007;13:635-638.

35. Maxia C, Perra MT, Demurtas P, et al. Relationship between the expression of cyclooxygenase-2 and survivin in primary pterygium. Mol Vis. 2009;15:458-463.

36. Kampitak K, Leelawongtawun W, Leeamornsiri S, Suphachearaphan W. Role of artificial tears in reducing the recurrence of pterygium after surgery: a prospective randomized controlled trial. Acta Ophthalmol. 2017;95(3):e227-9.

37. Sabater-Cruz N, Dotti-Boada M, Rios J, et al. Postoperative treatment compliance rate and complications with two different protocols after pterygium excision and conjunctival autografting. Eur J Ophthalmol [Internet]. 2020 [cited 2020 Aug 6]. Available from: https://pubmed.ncbi.nlm.nih. gov/32338523/. doi: 10.1177/1120672120917335.

38. Anguria P, Ntuli S, Carmichael T. Young patient's age determines pterygium recurrence after surgery. Afr Health Sci. 2014;14(1):72-76.

39. Varssano D, Fischer N. Pterygium Excision With Conjunctival Autograft: True Survival Rate Statistics. 2013;32(9):1243-50.

40. Huerva V, March A, Martinez-Alonso M, Muniesa MJ, Sanchez C. Pterygium surgery by means of conjunctival autograft: Long term follow-up. Arq Bras Oftalmol. 2012;75(4):251-255. 